\title{
GRAZING MANAGEMENT IN SPRING AND SUBSEQUENT DAIRY COW PERFORMANCE
}

C. J. Hoogendoorn, C. W. Holmes, A. C. P. Chu Departments of Animal Science and Agronomy, Massey University

Abstract

Two levels of grazing intensity were unposed on pasture during a spring-time pre-treatment period in two years at Massey University's Dairy Cattle Research Unit. The two grazing intensities were $\operatorname{lax}(L)$ 2000-2500 kg DM/ha residual herbage mass (RHM) and intense (I) 1000-1500 kg DM/ha RHM. imposed for 2 grazing rotations. During this period, net herbage accumulation (NHA) on the $L$ wards was approximately twice that on I wards. However, by early summer, NHA was greater on the than L wards.

Subsequently, during the experimental feeding period in early summer, herbage on the I wards contained lower percentages of reproductive tillers, grass stem, and senescent matter, and was of higher digestibility than herbage on the $L$ wards.

During the feeding period, cows grazing the Iswards had greater yields of milk and milk fat than cows on the $L$ wards when offered both generous and restricted daily herbage dry matter allowances. The effect of sward type on dry matter intake (DMI) was dependent on dry matter allowance. However, when a common allowance of leaf was offered, DMI, milk and milk fat yield were not significantly affected by sward type on offer.

The results emphasise the importance of maintaining green, leafy wards into late spring and summer In order to maximise milk yield per cow at this time. This was achieved by maintaining a RHM of no more than $1500 \mathrm{~kg}$ OM/ha throughout spring by Imposing sufficiently high stocking rates.

Keywords: residual herbage mass, sward characteristics, dry matter allowance, leaf allowance, dry matter intake, milk yield.

\section{INTRODUCTION}

In spring, dairy farmers often face a management dilemma: whether to feed cows at a generous herbage dry matter allowance and risk consequent decreases in sward quality and milk yield in summer, or to restrict cows in spring in order to maintain sward quality and risk an immediate decrease in cow performance. The present study was conducted to obtain information on sward response in spring and early summer to variations in grazing intensity in spring, and to assess the performance of cows grazing these swards in early summer.

\section{MATERIALS AND METHODS}

The study was conducted at Massey University's Dairy Cattle Research Unit, situated on Tokomaru silt loam, consisting of a $15-30 \mathrm{~cm}$ layer of heavy silt above a mottled clay loam. In each of two years ryegrass/white clover swards were grazed either laxly $(2000-2500 \mathrm{~kg}$ DM/ha residual herbage mass $(\mathrm{RHM}),=\mathrm{L}$ swards) or intensely $(1000-15000 \mathrm{~kg} \mathrm{DM} / \mathrm{ha}$ $\mathrm{RHM}$, = I swards) by lactating dairy cows and dry stock over two 21-day rotations (Hoogendoorn 1986). This preparation period commenced in early October.

The experimental feeding period began in mid-November in both years. In year 1 , lactating dairy cows were offered either a generous or restricted daily herbage dry matter allowance (DA) of 48 or $12 \mathrm{~kg}$ total DM/cow daily respectively, on the two sward types for a period of 3 weeks. In year 2, cows were offered a common allowance of leaf dry matter (LA) (grass and clover leaf) of $16 \mathrm{~kg}$ leaf DM/cow daily on the two sward types for a period of 5 weeks.

Sward characteristics were measured at intervals of 3 weeks over the OctoberDecember period. Animal performance was measured during the feeding periods in both years. Herbage dry matter intake (DMI) was estimated using the difference method (Leaver 1986). 
Analysis of variance was performed on sward measurement data and on DMI data according to a completely randomised model. Milk yield data were subject to analysis of covariance according to a randomised block design in year 1 and according to a completely randomised design in year 2, using repeated measurements analysis. All data reported are least squares means and their standard errors.

The effects of spring grazing intensity on sward characteristics in spring and early summer were identical for both years, and only the sward data for year 2 will be presented.

\section{RESULTS}

Differences in sward characteristics between the $L$ and I swards were observed after 3 weeks or one rotation of differential grazing in October (Table 1 and Figure 1). These differences were characterised by $L$ swards, with higher pre-grazing herbage masses, having herbage with higher values for percentages of reproductive tillers, grass stem, and senescent matter, but lower values for percentages of leaf, clover and dry matter digestibility. In October and November the rate of NHA was greater for L swards than I swards; this situation was reversed in December.

In year 1, at both generous and restricted DAs, those cows grazing the I swards had greater milk and milk fat yields than cows on the $L$ swards (Table 2). When offered a restricted DA on the two swards types, DMls were similar for both groups of cows. However, at a generous DA, those cows grazing the I swards appeared to consume more dry matter than cows on the $L$ swards. In year 2 , the DAs required to offer a common $L A$ of $16 \mathrm{~kg}$ leaf DM/cow daily were 81 and $35 \mathrm{~kg}$ total DM/cow daily for the $L$ and I swards respectively. Nevertheless, DMI, milk and milk fat yields were not significantly affected by sward type on offer.

Table 1: The effect of grazing intensity in spring on sward characteristics throughout spring and early summer. October $=3$ weeks post initial differential grazing: November $=3$ weeks post second round of differential grazing: December $=3$ weeks post grazing by experimental groups of cows.

\begin{tabular}{|c|c|c|c|c|c|}
\hline Month & Sward type & $\begin{array}{c}\text { Total pm-grazing } \\
\text { herbage mass } \\
(\mathrm{kg} \mathrm{DM} / \mathrm{ha})\end{array}$ & $\begin{array}{c}\text { Net herbage } \\
\text { accumulation } \\
\text { (kg DM/ha daily) }\end{array}$ & $\begin{array}{c}\text { Percentage } \\
\text { reproductive tillers } \\
\text { (\% of total tillers) }\end{array}$ & $\begin{array}{c}\text { Dry matter } \\
\text { digestibility } \\
(\%)\end{array}$ \\
\hline \multirow[t]{4}{*}{ October } & Laxt & 4210 & 106 & 63.0 & 70.2 \\
\hline & Intense & 1654 & 60 & 33.3 & 70.6 \\
\hline & SE (LSM) & 305 & 10 & 3.5 & 0.5 \\
\hline & sig. level & $* * *$ & $*$ & $* *$ & NS \\
\hline \multirow[t]{4}{*}{ November } & Lax & 4945 & 103 & 76.7 & 67.1 \\
\hline & Intense & 2019 & 57 & 26.6 & 71.6 \\
\hline & SE (LSM) & 97 & 6 & 11.3 & 0.3 \\
\hline & sig. level" & 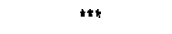 & & $* *$ & 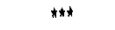 \\
\hline \multirow[t]{4}{*}{ December } & Lax & 3714 & 18 & 44.4 & 67.1 \\
\hline & Intense & 2069 & 55 & 16.7 & 71.9 \\
\hline & SE (LSM) & 17 & 6 & 6.0 & 0.3 \\
\hline & sig. level & $m$ & f.. & $* *$ & m" \\
\hline
\end{tabular}

$\dagger$ Lax $=$ wards grazed laxly in spring (2000-2500 $\mathrm{kg}$ DM/ha residual)

Intense $=$ wards grazed intensely in spring $(1000-1500 \mathrm{~kg}$ DMha residual $)$

\section{DISCUSSION}

The results of year 1 demonstrate the significant effect of sward quality on the late spring/early summer performance of cows offered either a generous or restricted allowance of total DM. The results of year 2 indicated that the decrease in milk yield on poor quality swards could be eliminated by offering an equivalent allowance of green leaf DM to those on high quality swards.

However, offering a very large allowance from a low quality sward resulted in large values for RHM (3500-3700 kg DM/ha), which would further decrease sward quality at subsequent grazings. 
Table 2: The effect of sward type and allowance on dry matter intake. milk and milkfat vield in earlv summer.

\begin{tabular}{|c|c|c|c|c|c|}
\hline Year & Sward Type & $\begin{array}{l}\text { Allowance } \\
\text { (kg DM/cow daily) }\end{array}$ & $\begin{array}{l}\text { Dry Matter Intake } \\
\text { (kg DM/cow daily) }\end{array}$ & $\begin{array}{c}\text { Milk Yield } \\
\text { (kg/cow daily) }\end{array}$ & $\begin{array}{l}\text { Milkłat Yield } \\
(\mathrm{kg} / \mathrm{cow} \text { dally }\end{array}$ \\
\hline \multirow[t]{6}{*}{1} & Laxt & 48 (total dry matter) & $161 \mathrm{btt}$ & $13.6 \mathrm{~b}$ & $0.63 \mathrm{a}$ \\
\hline & & 12 (total dry matter) & $7.9 \mathrm{a}$ & $10.5 \mathrm{a}$ & $0.54 \mathrm{a}$ \\
\hline & Intense & 48 (total dry matter) & $21.3 \mathrm{c}$ & $15.5 \mathrm{c}$ & $0.79 \mathrm{c}$ \\
\hline & & 12 (total dry matter) & $7.1 \mathrm{a}$ & $13.1 \mathrm{~b}$ & $0.68 \mathrm{~b}$ \\
\hline & & SE (LSM) & 0.7 & 0.6 & 0.04 \\
\hline & & sig. level & *** & "2* & \\
\hline \multirow[t]{4}{*}{2} & Lax & 81 (total): 16 (leaf) & 11.4 & 17.4 & 0.74 \\
\hline & Intense & 35 (total); 16 (leaf) & 11.9 & 17.1 & 0.81 \\
\hline & & SE (LSM) & 1.8 & 0.4 & 0.03 \\
\hline & & sig. level & NS & NS & NS \\
\hline
\end{tabular}

$\dagger$ see footnote Table 1
tt means within columns that are followed by dissimilar letters

are different at $P<0.05$ (orthogonal contrasts)

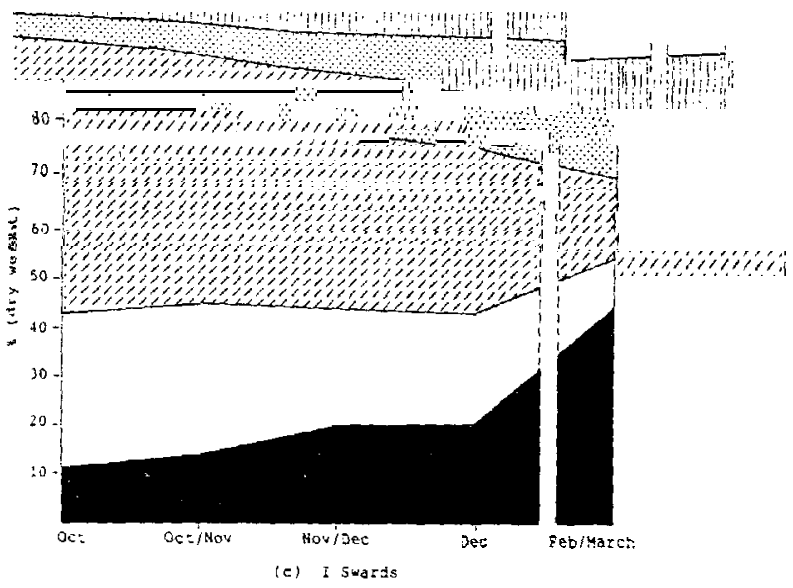

(c) i suards

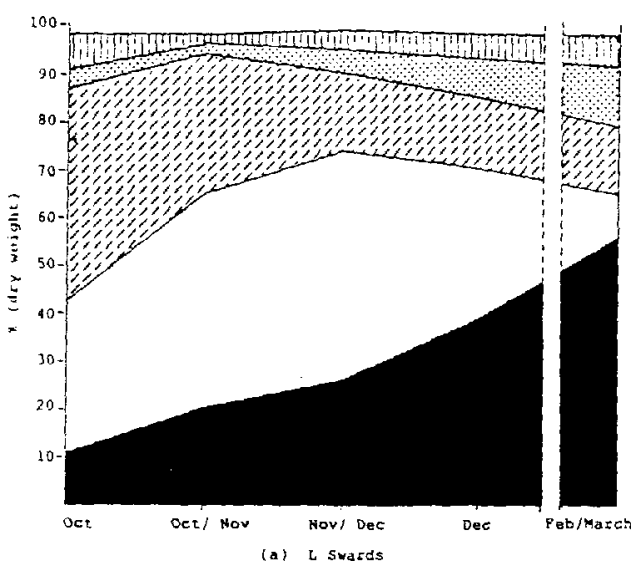

Figure 1: The percentage of grass stem, grass leaf, clover stem, clover leaf and senescent matter in the total pre-grazing herbage in spring and summer following Intense (I) and lax (L) spring grazing (see footnote Table 1). 
In the present study, cow performance was not monitored during the preparation period when diferential grazing intensities were imposed (October-mid November). In similar studies conducted in the UK (Baker \& Leaver 1986), Tasmania (Michell \& Fulkerson 1987) and New Zealand (Thomson et al. 1984; Bryant \& L'Huillier 1986). cow performance was monitored over the entire season. The milk and milk fat yield of those animals grazing more intensely was lower than those on more laxly grazed swards, during spring. However, this initial decrease in yield was more than compensated by a subsequent yield increase, in late spring and summer.

Not accounted for in these studies are the possible effects of spring grazing management on the reproductive performance of cows. There is a need for studies investigating the effects of grazing management in spring which involve detailed sward and animal measurements over the entire season.

However, in the present study, a residual herbage mass of no greater than $1500 \mathrm{~kg}$ DM/ha (residual herbage height of $4-5 \mathrm{~cm}$ ) during spring resulted in swards that had higher herbage quality throughout spring and early summer, and higher net herbage accumulation rates in early summer. Intense grazing during the period of reproductive growth in spring would necessitate high stocking rate and/or adequate conservation policies in order to cope with increased herbage growth at this time.

\section{Acknowledgements}

This project was partially funded by the Massey University Agricultural Research Foundation. Technical assistance was provided by R. A. S. McClenaghan, W. Nelson and R. Vernal.

\section{References}

Baker A-M.C.. Leaver J.D. 1986. Effect of stocking rate in early season on dairy cow performance and sward characteristics. Grass and Forage Science 41: 333-340.

Bryant A.M., L'Huillier P.J. 1966. Better use of pastures. Proceedings of the Ruakura Farmers' Conference, Hamilton 38 : 43-51

Hoogendoorn C.J. 1986. Studies on the effects of grazing regime on sward and daily cow performance. Ph.D. Thesis Massey University.

Leaver J.O. 1982. Herbage intake handbook. British Grassland Society, Hurley.

Michell P. Fulkerson W.J. 1967. Effect of grazing intensity in spring on pasture growth, composition and digestibility, and on milk production by dairy cows. Australian Journal of Experimental Agriculture 27: 35-40.

Thomson N.A., Lagan J.F., McCallum D.A. 1964. Herbage allowance. pasture quality and milkfat production as affected by stocking rate and conservation policy. Proceedings NZ Society of Animal Production 24: 889-898. 